\title{
Relations of Gender, Body and Sexuality: Students' Conceptions on Self-care Related to Teaching Sexually Transmitted Diseases
}

\author{
Roberta Ribeiro De Cicco ${ }^{1, *}$, Eliane Portes Vargas ${ }^{2}$ \\ ${ }^{1}$ Fundação Oswaldo Cruz, Instituto Oswaldo Cruz, PGEBS - RJ, Brasil \\ ${ }^{2}$ Fundação Oswaldo Cruz, Instituto Oswaldo Cruz, LEAS - RJ, Brasil \\ *Corresponding author: robertarcicco@gmail.com
}

Received July 18, 2013; Revised August 05, 2013; Accepted October 22, 2013

\begin{abstract}
Adolescence, a fundamental stage of youth development experienced by all young students, is marked by a moment of transition, when several changes take place, from attitudes, questioning and opinions to the passage towards sexuality, with a partner. During this stage, the body becomes loaded with connotations in relation to self representation and care, being interpreted in very specific ways by different societies and social groups. The study aims to present reflections on differences related to gender and body care found in the conception of young students between ages 17 to 20 from a class of secondary school in a State School located in the metropolitan region of Rio de Janeiro - Brazil encompassing sexuality. The results indicate distinct conceptions of gender related to decision making linked to sexual initiation, as well as body care in connection with the acknowledging of body signals and attitudes for STD prevention.
\end{abstract}

Keywords: gender, body, sexuality, youth, STD

Cite This Article: Roberta Ribeiro De Cicco, and Eliane Portes Vargas, "Relations of Gender, Body and Sexuality: Students' Conceptions on Self-care Related to Teaching Sexually Transmitted Diseases.” American Journal of Educational Research 1, no. 9 (2013): 366-374. doi: 10.12691/education-1-9-4.

\section{Teaching STD and the Learning of Sexuality}

This work talks about the way conceptionsof sexuality and body, related to the sexually transmitted diseases (STD) topic,are perceived by young students, concerning science teaching in the city of Rio de Janeiro, Brazil. Supported by sociological and anthropological perspectives, this study intends to understand sexuality as a social construct, in other words, as constructed in different ways throughout cultures and times [1,2] and means to draw attention to the fact that this theme presents a relevant connection between biology and subjective aspects, chiefly the sociocultural aspects $[3,4]$ that pervade teaching and learning of contents related to the STD topic.

Teenage sexuality, according to the biomedical concept, would be a discreet happening, with regularity of certain behaviors due to hormonal bursts and impulsivities common to that age, far away from cultural representativity $[5,6]$. However, according to the approach that supports the research, teenage sexuality corresponds to personal experimentations, relationships, fantasies, desires, beliefs, attitudes, representations, values, practices, gender roles and sexual culture, demystifying conceptions of purely genital aspects and/or of sexual initiation $[7,8]$.

Sexuality, approached in this research as a topic to be considered in thescience teaching, is understood as a by- product of different cultural scenarios constructed during a lifetime that stimulates autonomy for youngsters in relation to expressions and manifestations related to sexual practices, and not only as a body function born from biological reactions $[2,9,10]$. In other words, it does not relate only to the human being's reproductive abilities, but also to pleasure and the commitment of body, of our history, behaviors, affective relations and our culture $[7,8,9]$ expressing the singularities from subjects involved and ranging from biological and psychological to sociocultural aspects, in an articulated manner [11]. In such way, the construction of a sexual identity during adolescence is related to the constitution of sexualaffective relations with one's peers $[8,12]$ and the cultural process undergone by each.

According to this perspective the expression of sexuality regulates experience and manifestations of desire, of emotions, of demeanor and body practices in certain social contexts, which are established in the relations among peers, bringing forth in evidence the relations between society and the individual [10]. So, this socialization by the means of culture regulates livid experiences and the behaviors considered acceptable in different layers of society. Moreover, considering social practices, it must be taken into account their distinction according to the different sorts of societies and their referentials, which translates into distinct meanings according to the different sociocultural strata. So, we conclude that the manners in which we interpret sexual 
relations in each context enable several impacts in the experiencing of sexuality by individuals [10].

Learning and the individual behavior are by-products from what is culturally learned, as a part of a social construction where the process of schooling is included. The definition of culture, in order to substantiate the analysis of what is learned and how it is learned in the process of schooling related to the theme of this research, is the definition devised by [13] in which there is an appreciation of the context where social events and behaviors takes place, habits and proceeding are describedso that a critique is articulated regarding the unrestrained use of the concept of culture by society without due consideration over current conceptions of this notion.

"The concept of culture that I defend is essentially semiotic. As Max Weber believed that humankind is comprised of animals tied to webs of meanings weaved by humankind itself, I accept culture as these webs and its analysis; therefore, not as an interpretative science in search of meaning.”([13], p.15).

The author was trying to gradually oppose himself against a reductionist perspective where culture is defined as a set of rules transmitted from generation to generation within societies, regulating and attaching meaning to practices and perceptions of a given social group.

In this manner, from an understanding of sexuality in an historical-cultural perspective, it is relevant to consider, in the learning of sexuality, all the educational processes (formal, non-formal and informal) that exert influence on teaching in order to offer questioning and related evidence on how sexual education and sexually transmitted diseases prevention are based in pre-established concepts about body and gender relations as patterns of sexuality, which are also expressed in the proposed national school curricula $[14,15]$. It becomes clear, in the processes that influence teenager socialization, a decrease of the participation of family in the transmission of values related to sexuality and a increase of the participation of learning institutions as places of integration among equals, as pointed out in the listed bibliography.

Thanks to concerns regarding preventive aspects and/or the minimizing of risks in relation to sexually transmitted diseases, the sexuality of youngsters has been drawing attention and care from both health and educational departments, beginning with the establishing of public policies of sexual education in schools by the means of a transversal theme - Sexual Orientation [15]. However, this topic, usually and traditionally included in the range of concerns pertaining to the health field (health of teenagers and students), has been approached many times, especially in health prevention activities, mainly centered around information transmission.

\section{Sexuality, Bodyandgender: Social and Cultural Dimensions}

The adolescence period has been object of attention by the governmental sphere not only due to the care required during this life stage, but also due to different studies in several and varied fields of knowledge, including education and health, in national and international researches. Adolescence is characterized as a moment of transition, whenseveral changes take place, from attitudes, questioning and formation of opinions to the passage towards sexuality, with a partner $[7,8,9,12,16]$. During this stage, the body becomes loaded with connotations that are object of extreme concern during youth, with elegance and with care. However, during this phase, each culture will demand different attitudes or responsibilities from the individual and the accidents that arise can be interpreted in distinct manners [17]. In the field of human and social sciences, the body arises as a preferential anthropological study matter, where said studies point out that it is interpreted in very specific ways by societies and social groups [18]. In this perspective, it is understood that people assemble their own body socially as a result from the interaction with other people, where they produce qualifications that regulate meanings and values [19].

Considering the perspective of gender relations, the body suffers abrupt transformations, mainly among girls, and this biological factor also exerts influence in the imaginary of young boys and girls, requiring the reconstruction of their own self-image and their sexual identity $[11,20]$. It is from adolescence on that boys and girls start presenting different attitudes concerning sexuality [21]. Male and female trajectories differ, above all in how expectations and aspirations in relation to sexual experimentation are differentiated through gender $[8,9]$, whose representations also happen in the body and through the body, in specific cultures and specific ways.

According to data surveyed in the field literature, the genderinscription (male and female) in bodies happens contextually, in each culture and with its own signals. So, the construct of gender and sexuality occurs throughout a lifetime, through learning and exercising in different social and cultural spheres [2,22]. Gender can, therefore, be understood as a social construct, where rules, values, perceptions and representations are engraved. All these factors contribute to the construction of the subject's identity [23,24]. According to [25], "gender allows us to differentiate sexual practice from sexual roles attributed to women and men”. In this case, it is a fundamental element in the social relations based on differences perceived between genders, in other words, in the perception of what means to be a man and to be a woman.

The way teenagers of female and male gender express their doubts and want for information related to sexuality, diseases and contraception are distinct. This difference is influenced by issues that comprise family relationships, as well as relationships with his or her equals and sources of information $[9,26]$. While girls debate, solve their doubts and confide with the maternal figure, boys identify themselves mainly with the fathers, albeit sometimes with the mother figure and with their peers, wherein the later exert a more relevant role in a group of boys than in a group of girls [26].

As previously mentioned, the approach to the STD topic, considered a health issue, happens to be limited, most of the time, to the diffusion of information on transmission and treatment. It is important, however, to highlight that the health-disease process and the way that individuals understand health related events are closely connected to the process of socialization determined by culture, which also guides experiences and subject behavior [27].There are no exact definitions for the healthdisease relation or for what the individual feels or 
perceives as health or as disease, so, in other words, health does not have a meaning in itself [28]. In this sense, the meanings each individual attributes for himself or herself in relation to the health-disease process have a historical, social and cultural imprint, which are the set of characteristics responsible for the conception that each individual or social group brings forward about their own situation. Reference [29] point out that the conceptions of health and disease are associated with biological, social, economical, environmental and cultural factors and that the "state" of one person's health may be related to the life style and social and cultural universe.

Taking into account the purpose of the study, oriented towards the understanding of events associated with teaching of sexually transmitted diseases in the school context-recapitulated here as being the relations established between different actors involved in this process - thisstudy presents some reflections on the differences pertaining to gender among young students that reside in the conceptions belonging to sexuality related to the STD topic. These differences are translated in the concerns reserved to the body, as well as in the understanding of the health-disease process, in the decisions and planning that involve sexual initiation, in the preventive practices and in the choice of sources of information on issues relating to sexuality. The understanding of this matter is important, to the extent that the STD topic in the school context influences a whole set of issues, including the Science teaching structured as having its referent in the biological concepts addressed in the formal teaching. Further more,it is considered a transversal theme in official documents, becoming, according to the chosen perspective, relevant for the teaching and learning of this topic.

\section{Methodological Strategies}

The study intends to be a qualitative research developed according to the socioanthropoligoc perspective where many methodological strategies were used in order to collect data, namely: analysis of official documents in the fields of health and education, including didactic books on Biology; the participant observation of formal teaching; interview with students of ages ranging from 17 to 20 years and with Biology teachers of secondary school aged 43 to 50, carried out in a state school of the metropolitan region of Rio de Janeiro - Brazil.

Taking into account the aforementioned strategies, the methodology used in the research was subdivided as following: (a) analysis of eight compilations of didactic books from the Biology Catalogue approved by the National Program of Didactic Books for secondary school (Programa Nacional do Livro Didático - PNLEM) [30]; (b) analysis of documents from the Guidelines for Education and Health, (c) participant observation of the school context and (d) individual and group interviews with teachers and students of secondary school.

The analysis of documents paired with data collected through participant observation in the field work focused on the STD content featured in the didactic textbooks collections of Biology approved by the Ministry of
Education (MEC) [30] ${ }^{1}$, as well as the regulations of the National Curricular Parameters [31], [32], of Curricular Guidelines and Pedagogical Proposals of the teaching institution taking part in the study correlated to the official regulations of the STD/AIDS Department and Viral Hepatitis [33] seeking to understand the contextualization of these guidelines on the process of teaching in relation to their foundations, historical aspects and internal articulation.

The analysis of compilations (a) was comprised of five stages. The stage (1) consisted of surveying the Biology Catalogue as approved by PNLD with the following collections:

1) Biologia, Linhares, S.e Gewandsznajder, F., 2004.

2) Biologia, Lopes, S.e Rosso, S., 2004.

3) Biologia, Laurence, J, 2005.

4) Biologia, Favaretto, J.A. e Mercadante, C. 2003.

5) Biologia, Vitória Régia de Adolfo, A, Crozetta, M. e Lago, S., 2005.

6) Biologia, Paulino, W.R., 2006. (3 volumes)

7) Biologia, Amabis, J. M e Martho, G.R., 2006 (3 volumes).

8) Biologia, Júnior, C. S. e Sasson, S.; 2005 (3 volumes).

9) Biologia, Frota-Pessoa, O., 2005 (3 volumes).

The stage (2) of the analysis of these compilations consisted of the identification of criteria and the development of an instrument for data collection. In order to analyze how the Biology textbooks aimed at secondary school approach the STD issue, a bibliographic inspection was conducted, wherefrom a renewed discussion was enforced and the parameters of analysis were adapted in accordance with the works that contemplate the sexual education topic: [34]; health: [35] and [36] and biology: [37], in the analysis of learning materials.

An evaluation card was developed with the following focuses: topic placement: chapters with reference to living beings or reproductive physiology; structure and text format: supplementary texts, reference to other authors, additional information sources, reference to other chapters of the collection and to the Official Health Programs; content: approach, prerequisites, which STD were included in each chapter, supplementary information, procedures of prophylaxis and treatment, initiatives for contextualization of the topic; language: suitable for the target audience or for specific groups, reference to campaign symbols, occurrence of stereotypes and stereotyped situations and emphasis on certain genders, races or ethnical groups; illustrations: quality, bibliographic sources, coherence with the content, advertising of Healthy Ministry or of interaction of youngsters and phases in the evolution of diseases. Such categories aim to identify the adequacy between scientific content in the textbooks and the cognitive universe of those for whom this material is designed, once it is an information resource for inside and outside of the school environment. The up to date factor in the contents is going

\footnotetext{
${ }^{1}$ A part of the conclusions related to the analysis of didatic Biology collections from PNLEM then in use by the year of this study (2010) regarding the STD topic in didatic texts is described in another article. In this note, the information related to that article was deleted in order to have no authorship identification during evaluations process. Upon approval, the reference shall be duly adjusted enabling the identification of the article.
} 
to be based in those supplementary texts which are intended to approach issues of the student's everyday reality.

Stage (3) consisted of the analysis of each compilation individually, stage (4) is comprised of thoughts on similarities and differences between the Biology collections analyzed and the stage (5) is a synthesis of all observations of STD related contents found in the collection used in the chosen school, according to a comparative analysis of the Biology content in the textbook and the guidelines of the STD/AIDS and Viral Hepatitis Department.

The analysis of the guidelines for Education and Health (b) consisted of three stages: (1) collecting of the Reference Board on STD from the STD/AIDS and Viral Hepatitis Department of the Health Ministry; (2) the designation of proposed aspects in the Official Programs of Education and Health concerning proposals for articulation of the STD transversal theme to the school context and (3) comparison between proposals.

The field work carried out together with the documental analysis was developed based on observation of the school environment and interviews with teachers and students of secondary school of the chosen school.

The participant observation of the school context (c) was carried out between August 2010 and April 2011. The contact with sources interviewed was achieved throughout field work based on the weekly familiarity with students and teachers of the institution. In such manner, it is possible to follow the development of the approach on STD inside the official Biology program proposed by the guidelines of education for secondary school, including minute observation of strategies used in dealing with the Biology contents (living beings and reproductive physiology) that are bound to approach the topic, as well as the teacher/student relation in the teaching context and the interactions between individuals taking place in school environment.

Due to peculiarities observed and the possibility of exploring with greater depth the students' and teachers' perspectives in relation to the approaches on the STD theme in the formal teaching context, we proposed two types of interview. Interviews with students and teachers of the institution (d) were structured based on the research objective and field observations, subdivided in two stages: group interview and individual interviews. The group interview was carried out in the class number 2004 on school year 2010, comprised of 25 students attending from a total of 33 enrolled students, considering the topics: knowledge and conceptions on diseases, transmission and prevention, practices related to STD, information and formal and non formal school context. The individual interviews, conducted between March and April 2011, were comprised of two phases: individual interview with students and individual interview with Biology teachers of secondary school.

The individual interviews with students were concluded with a total of 14 interviews ( 7 boys and 7 girls), made use of the saturation survey technique. The interviewees were chosen according to the participation on the previous stage of the group interview. The teachers' interviews were conducted with three interviewees who constitute the total of Biology teachers working in secondary school in the chosen institution. Two different guidelines were developed, one for students (a modification on the interview guidelines used in the first stage group interviews, oriented as such to develop issues that had arisen in that previous stage), and another one for teachers (comprising STD in a formal context, conceptions on the didactic textbook and the non-formal contexts).

In the reflection presented here we call attention especially to some of the aspects found in the perception of young students on sexuality and on prevention of diseases regarding differences in relation of gender, all these topics intrinsically related to STD and advanced in the broader study.

All partakers in the study were informed of their right of refusing to take part on the research, as well as the freedom and secrecy in relation to their answers by means of a Term of Consent approved by the Research and Ethics Council $^{2}$.

\section{Body, Gender and Practices on Prevention Related to STD}

When the STD topic was introduced in the school environment, in the research context, we could observe some issues related to subjects' sexuality arising in connection with it and beyond the scope of the biologic content refereed in didactic material, as it should be predictable, taking into account the supplementary nature of materials for the teaching practice. Among them, there are the orientation and conceptions of youngsters, notwithstanding the conceptions of teachers which are not going to be tackled in this work, about sexual initiation which gives rise to questioning in relation to attitudes and care concerning this event.

A priori, and according to recommendations for actions of disease prevention, the first sexual intercourse should be protected and planned. However, it can be inferred from the young people discourse that it does not always happen that way, especially in respect to the expression of differentiated experiences between boys and girls and between the sexually initiated or in expectations among the non initiated [26].

"It was only after the first time that I started having more care (...) I forgot, that's why I told you, we don't have the judgment” (José, age 17, male).

"I think in everything, how to use, what to do, what happens then. But I think in everything, especially in the diseases (...) Yes, I plan everything, because it is something we have to take care then, so that nothing goes wrong, so that there are no consequences later" (Andressa, age 17 , female).

"... after we both are tested and we are both clean, then ok, without testing, no way” (Geovanna, age 17, female).

Among attitudes related to sexual practices, there are those that assert the adoption of preventive measures only after the first sexual intercourse, those that since first intercourse have adopted these measures and those that assume the intention of withdrawing it after laboratorial testing. There are also those that translate their expectations in politically correct discourses copying the

${ }^{2}$ The research was reviewed by the Research and Ethics Council of CEP/FIOCRUZ andAPPROVED according to the rules and guidelines of the Resolution 196/96 of the National Health Council. 
medical and educational orientations recommended to this audience. Those that take these stands and discourses reflect a good portion of the results found in the analysis of Biology collections that emphasize recommendations oriented to STD prevention, without, however, identifying and questioning them in the students' everyday life. The sexual initiation of these youngsters, therefore, albeit having in a first glance happened sometimes protected or planned, can, from what young Geovanna tells, in terms of planning, which in the conception of Andressa imbued the first protected sexual intercourse, be considered as tending to change during the relationship, as the use of protection could be even abandoned. In other words, the trust relationship established between couples, in the conception of Geovanna, is a fundamental issue in the adoption of preventive measures. According to [38], many young people identify prevention as an important sexual practice, although they refuse to maintain it as long as they start trusting their partners.

This diversity of differentiated expressions and practices followed by these individuals concerning preventive measures may be related not only to the previous knowledge of the diseases, but also to the understanding of health and disease and of necessary care with bodies, differentiated by gender, of these groups.

When researched students manifested themselves in relation to cautions, we were able to observe some evidence on how they understand the symptoms and first symptomatic signs of STD and about the process of disease identification. Some students showed worry in respect to STD infections, the perception of most common symptoms and difficulties in identifying body signals denotative of STDs.

"Oh, AIDS, they say that the person begins getting weaker, the immunological system fails. The person gets thinner, and then it attacks other organs, right... the lungs... the person gets weaker. But they say that the signals sometimes don't appear instantly, and then the person only discover about it after a very long time or even dies without knowing.” (Regina, age 17, female).

"They say that when the person gets AIDS, the person gets thinner and becomes anemic, I don't know... I find it hard to identify it at first glance, but then after some time I think it is possible. If the person sees a doctor, the person will know it for sure, right” (Jefferson, age 18, male).

Spotting symptoms, for some students, means the possibility of treating diseases earlier. According to them, premature diagnosis is fundamental for treatment and cure of most STD, although they know that AIDS is still not curable. This perception goes along with what is found in specific literature and in our own findings, in which a premature diagnosis can help in a more efficient treatment. Another very debated issue is that identification of symptoms is an easy task, however, relate symptoms with the respective disease is a challenge, as there are symptoms common to more than a disease and these are little explored in the contents, materials and classes reserved to this theme. The analysis of Biology textbooks approved by PNLEM/2009, and, specially, of the collection used in the researched school, pointed out that only a few texts portrayed illustrations and displayed a correlation between image and content. There were not observed images in relation to diseases, etiological agents and/or indicative signs of diseases. The existing correlations included publicity information with advertising campaigns from the Health Ministry on AIDS prevention and the use of condoms. Also, on the didactic aspect, the Biology classes related to the theme and provided in the learning institution linked to the study were ministered orderly following the contents in the textbooks, although many times the teacher would abandon their proposal and conduct classes according to students' doubts and interests. In this manner, we were able to firstly understand the reason of some assertions affirmed by students in relation to identifications of body signals.

"You may want to fill in those symptoms with any other thing, unless you really can see something in your intimate parts, then you will see a doctor" (Geovanna, age 17, female).

"Pains, spots in the skin, discharges, things that you could do and now you can't do anymore in relation to your organ. But it is spots, pus and discharge. I would not be able to say [if there are any STD] but if you have just had intercourse and some days later there are pains, redness, dots, warts, pus, discharge, then surely you should see a doctor" (Andressa, age 17, female).

Information on STD conveyed in the STD/AIDS and Viral Hepatitis Department of the Health Ministry and also analyzed were supplementary to the contents found in the didactic works being used in the learning institution linked to the research. This information also presented itself as an important source for the topic approach in the school context. In this context it is considered very important the development of strategies able to join together several sources of information (from areas of health and education), such as the didactic material available for schools and information conveyed by the STD/AIDS and Viral Hepatitis Department for the identification of different kinds of sexual infections and ways of contamination associated with STD by students, whose data demonstrate they obtain a satisfactory degree of knowledge in this area [7,39].

In connection to care related to the body, young people shows distinct conceptions of gender in their discourses. They signal a greater orientation for care in the feminine gender while point out that men are more vulnerable to contamination by STD, due to their ingrained behavior in society.

"Girls are more careful with prevention. For boys, with one piece of information it is already fine. For women, they always want to know more, they are more interested in the subject. Because it is something like... everyone likes it, sex is pleasurable, it is nice. But the boys don't care much for this [prevention]. They always want to have it the first time and it is just to get it done, more to make an impression to the others. But not the girls, they want to know more information, they are interested in the subject, they want everything to be perfect so that there won't be trouble later" (Andressa, age 17, female).

"I think men [have more intercourse]. Because they just let their excitement takes over. We are more careful, we use condoms and they don't” (Suelen, age 17, female).

"I think boys, men are more reckless, they don't like to use this stuff [condom], don't like to take prevention" (Rafael, age 18, male).

There are also those who assign responsibility of contamination to the girl because she allows men not to 
use preservatives during intercourse when such request is made.

"I think it is the girls that are conceding the boys" wishes, they say the condom is uncomfortable and that they don't feel pleasure and the girls don't use it” (Graça, age 17 , female).

The perception that male or female behavior is inherently different may be inscribed in conceptions of social groups and in the meaning attached to their experiences. These typological definitions are implicit in the culture of a certain group and they end being reflected in the image an individual composes of self and of the other $[18,27]$. When assessing that more boys or more girls are infected, they end up forgetting that isolated attitudes from any one of the genders are liable to bring consequences for both, independently of kinds of relation each one establish with their peers. Also in this context, there are some that does not express a standpoint biased in gender and verbalize discourses that equal both in what regards these attitudes.

The behavior defined for each group is also associated with using or not using preservatives and consequently to the attitude concerning prevention. In what relates to the prevention of STD, there are gender differences in the students' conceptions.

"The boys are more careful. (...) I had one experience already... we were dating for some time, but it was him, we had never talked about it, but it was him that took the condom. And then I said: hey, why do you want to use it? I want because it is prevention and I also don't want to be a father. He already was thinking something like: I'll use it, well, I don't know her, don't know if she has a disease or not. And I was not, I couldn't care less” (Tatiana, age 18, female).

What draws our attention to Tatiana's testimony is her standpoint in relation to the tendency of boys having a greater concern with prevention, in spite of her account regarding the attitude of a single young boy that contradicts her preconceptions about male attitude on this subject. Such a statement indicates the strength of representations that sometimes appear distant from lived experience, as well as scientific knowledge received in the process of teaching and learning. Such observations induce us in believing that some representations and lived experiences acquire such a meaning that youngsters end up assuming them as absolute truths. For [12], spontaneous and less thoughtful practices of sexuality among young people tend to reinforce stereotypes of gender and interfere in the adoption of preemptive measures. Statements from the young people in our study exemplify this aspect:

"Oh, I think boys are careless, they think they are going to pleasure themselves and don't worry if they will catch a disease or if they already got one and others are going to catch it, they have less concern” (Regina, age 17, female).

"I think men take less caution because they act on impulse. They feel an urge, you know, and they forget. It happened with me once, with my girlfriend. The woman is always like, no, and I don't know, and you have to put a condom, take some pill. The man acts on urge.” (Jefferson, age 18, male).

The student above justifies his viewpoint in connection with the adoption of preemptive measures alluding to an incompatibility between his urges, as a gender related attribute, and the necessary planning for using a contraceptive. The trend in this kind of perception, therefore, is to delegate this function to the women, which, according to this young man, display more self control and concern with these issues. This viewpoint assumed by Jefferson demonstrates the existence of different conceptions of sexuality among genders which are responsible for modeling preemptive attitudes and sexual practices.

The construction of gender and sexuality happens during a lifetime, starting with learning and practices in social and cultural spheres [22], inscribing values and perceptions that contribute to the construction of the subject's identity [23,24]. According to [18], meanings are construed based in the experiences of a certain social group. Bodies receive signification based on the cultural construction of subjects. This signification is continually altered by this very culture, whence the instability ascribed to the body arisen from desires and necessities that are judged important $[2,19]$.

The different standpoints on gender are also inscribed in the way teenagers achieve their information on sexuality, contraception, pregnancy and sexually transmitted diseases. Such attitudes are distinguished according to the position attributed to family, groups of peers or collective sources such as health services, schools, television, magazines and books [26]. Analysis indicate, besides differences regarding the occasion of seeking information, differences pointed out by teenagers in discourses on how they obtain their information and dialogues with partners and/or informers.

Among boys that are already in a relationship, thoughts and notes on dialogues with the partner are based on the sense of care for and/or teaching each other. Although the partner would be the fundamental person in this exchange of information, some people assert that parents, brothers and even friends play important roles in this process. During adolescence, as youngsters seek socialization of sexuality, they end up ascribing importance to their group of peers, since they credit value to social interactions and to the conversations on sexuality shared with them, due to the familiarity of language [2,40,41,42].

"I talk with her [his girlfriend]. I think it is important, necessary... she is younger than me, you know, I have more experience. (...) Oh, sometimes I talk about it with my mother, but not with my stepfather. With friends, also the older ones and such, but in general with my mother (...) I trust her because she would not like to hurt me" (Jefferson, age 18, male).

"It is nice, to know more about each other”(José, age 17, male).

Among girls, the dialogue with the partner also stands out on statements from the ones already in a relationship. However, even those girls confirm their mothers as key sources of information with whom they can be intimate enough to talk and solve doubts. Among the interviewed girls who were not sexually initiated, the discourse about sources of information is very similar. They allude to the importance of conversation with the partner, through other informers or sources of information, besides also noting as a highlight the mother figure, as well as seeking medical professionals, teachers and books.

"I try to talk with my parents and my doctor" (Graça, age 17 , female). 
"It is necessary to talk. When we don't have any experience, we seek books, we ask our parents. I go and I ask my mother, I really talk with her” (Geovanna, age 17, female).

"I don't have any dialogue with my parents on this subject, so I talk with my friends. And I seek books, magazines related with it, how to take prevention, how to be careful. When I have a doubt I really ask the teacher" (Andressa, age 17, female).

So, collected data points out that the mother figure stands out as one of the main sources of information for girls, even though she plays important role in socialization of boys, especially concerning pregnancy and contraception [26].

Also on differences of gender between boys and girls, researches on first information on sexual intercourses, contraception, pregnancy and sexually transmitted diseases, [26] remark that among interviewees of both sexes, sexually initiated or not, most of them seldom mention doctors and health services as a source of information. However, they indicate the mother figure and the school as main sources of information concerning pregnancy and contraception, same result as observed in our findings.

Information on STD/AIDS assumes, therefore, a more institutional feature and the school and consequently teachers earn a relevant role in this process. However, it can be noticed in students' discourses the few references to didactic works used in the school environment or to programs concerning STD control. Such a fact can be understood to the extent that the didactic works deal with the STD theme mainly in topics of supplementary reading, which can or cannot be discussed in the school environment, being the teacher's decision, once most texts emphasize AIDS in neglect of other diseases and due to the purpose of discussing the Biology contents, ignoring the aspects relating to sexuality, as seem during this research, which tends to rise relating to the discussion of said theme.

In regard to the programs concerning this theme, the minimal repercussion among students may be exemplified by the absence of more objective and active proposals for the school environment of this study, as well as of more supported information, once even though being part of a transversal theme, STDs are developed strictly under the Biology and its teachers' focus. So, information on this issue ends up, therefore, being a privilege of mother figure and peers. We should, therefore, consider that the dialogue with peers and persons credited with truth are decisive for the learning of issues related to sexuality [40] and for the establishment of an interaction among parts [41]. Still concerning the social interactive perspective according to Vygotsky, the school, as a place of prominence on interactions among teenage peers, of intimacy and learning, should place itself as an environment for the development and discussion of proposals comprising social and cultural aspects relevant to the understanding of issues related to the sexuality of subjects.

\section{Conclusions}

Teaching STD encompass more than the scientific concepts that permeate contents of Biology associated to the said topic, as observed in the development of these research and in dialogue with the specific literature. It encompasses the understanding of youngsters on issues related to sexuality and sociocultural aspects found on interactions that compose formal teaching. In such way, understanding of subjective aspects encompassed in the perceptions of students in the process of learning constitutes a relevant aspect to be considered in the teaching of Sciences, to the extent that they are promoted in a significant manner in the acquisition of scientific knowledge related to the theme.

However, cultural aspects inherent to "how to teach Sciences" impose limits to the pedagogic practices and to the students' learning. According to this perspective, the identification of themes for analysis associated with contents of Science teaching, such as the ones observed in evaluations of didactic textbooks, emphasize the existence of a relation between scientific knowledge and its function in society.These research findings, in conformity with literature, portrayed that STD contents are associated with both themes: living beings and reproductive physiology. When the theme associated with the living beings chapter is worked, the discussion roughly befalls in the territory of biological aspects and its implications in the individuals' health. When the same content is seem associated with reproductive physiology, the teacher could potentially approach other perspectives associated to the sexuality of individuals using as a starting point the dialogue established in class and that rises according to questions and/or doubts. However, the emphasis of this approach tends to regress to the use of contraceptive methods aiming towards pregnancy prevention (Altmann $[20,43,44,45])$.

Such contents, when considered based on the gender relations perspective, pose other challenges. The conceptions of subjects taking part in the process of teaching and learning and their perceptions on gender differences found in the decision making process concerning the sexual initiation and attitudes of STD prevention are circumscribed by more than an issue of information access or scientific knowledge in the teaching context. These events are construed by cultural, historical and social issues that permeate the environment between the received information and the sexual behavior adopted in relation to prevention, as well as comprehension of dynamic conditions of health and disease and cares with the body. To understand these processes depends, therefore, of a broader comprehension regarding healthdisease relations and construction of scientific knowledge alongside individuals in the teaching-learning relation, in specific contexts, once these are related to complex phenomena joining together biological, social, economical, environmental and cultural factors in need to be considered.

The expression of sexuality centered in the experience of teenagers happens inside of a cultural context implicating different conception of gender related to body care and understanding of health and disease conditions. In this sense, it is important to work the STD theme in the teaching context acknowledging how these cultural aspects emerge from the analysis of themes addressed by teachers with their students. So, we believe we contributed to the discussions that emphasize an existing gap between the construction of biologic knowledge in the context of 
Science teaching and subjects' experiences and expectations. Finally, we point out as relevant the necessity of considering the addressed aspects when discussing different strategies and possibilities of approaches to the STD topic in the teaching and school contexts.

\section{Acknowledgements}

\author{
Support: Capes/CNPQ
}

\section{References}

[1] Parker, R. Cultura, economia política e construção social da sexualidade. In: LOURO, G. L. (Org.). O corpo educado: pedagogias da sexualidade. $3^{\text {a }}$ ed. Belo Horizonte: Autêntica Editora, 125-150, 2010.

[2] Louro, G. L. Pedagogias da sexualidade. In: LOURO, G. L. (Org.). $O$ corpo Educado: pedagogias da sexualidade. $3^{\mathrm{a}}$ ed. Belo horizonte: Autêntica Editora, 07-34, 2010.

[3] Brêtas, J.R.S.; Silva, C. V. Orientação sexual para adolescentes: relato de experiência. ActaPaulista de Enfermagem. 18 (3).São Paulo, 2005.

[4] Orlander, A. A.; Wickman, P. Bodily experiences in secondary school biology. Cultural Studies of Science Education, Germany, 13.569-594, 2011.

[5] Paiva, V. Sexualidades Adolescentes: escolaridade, gênero e o sujeito sexual. Texto de apoio do Curso de Especialização em Avaliação de Programas de Controle de Processos Endêmicos, com ênfase em DST/HIV/AIDS - Dimensão Técnico-operacional - MLP extraído de Sexualidades Brasileiras. Rio de Janeiro: Relume-Dumará, 213-234, 1996.

[6] Shoveller J.A., Johnson J.L., Langille D.B., Mitchell T. Sociocultural influences on young people's sexual development . Social Science \& Medicine, 59 (3). 473-487, 2004.

[7] Castro, M. G.; Abramovay, M.; Silva, L. B. da.Juventude e sexualidade. Brasília: UNESCO, MEC, Coordenação Nacional de DST/AIDS, Secretaria Especial de Políticas para as Mulheres, Instituto Airton Sena, 2004

[8] Heilborn, M. L. Experiência da Sexualidade, Reprodução e Trajetórias Biográficas Juvenis. In: Heilborn, M. L.; Aquino, E. M. L.; Bozon, M.; Kanuth, D. R. (Orgs.). O Aprendizado da Sexualidade: reprodução e trajetórias sociais de jovens brasileiros. Rio de Janeiro. Garamond e Fiocruz, 29-59, $2006 \mathrm{~b}$.

[9] Heilborn, M. L. Articulando gênero, sexo e sexualidade: diferença na saúde. In: Goldenberg, P.; Marsiglia, R. M. G.; Gomes, M. H. A. (Orgs.). O Clássico e o novo:tendências, objetos e abordagens em ciências e saúde. Fiocruz: Rio de Janeiro, 197-207, 2003.

[10] Heilborn, M. L. Entre as tramas da sexualidade brasileira. Estudos Feministas, Florianópolis, 14 (1). 43-59, 2006a.

[11] Mandú, E. N. T.; Corrêa, A. C. P. Educação Sexual Formal na Adolescência: Contribuições à Construção de Projetos Educativos. Acta. Paulista de Enfermagem. São Paulo, 13 (1). 27-37, 2000.

[12] Alves, C. M.; Brandão, E. R. Vulnerabilidade no uso de métodos contraceptivos entre adolescentes e jovens: interseções entre políticas públicas e atenção à saúde. Ciência \& Saúde Coletiva, Rio de Janeiro, 14, (2). Mar/Abr, 2009.

[13] Geertz, C. "Uma descrição densa: por uma teoria interpretativa da cultura”. In: A interpretação das culturas. Rio de Janeiro: Zahar, 13-41, 1989.

[14] Dinis, N.; Asinelli-Luz, A. Educação sexual na perspectiva histórico-cultural. Educar, Editora UFPR, Curitiba, 30. 77-87, 2007.

[15] Brasil. Parâmetros Curriculares Nacionais: Temas Transversais: Orientação Sexual.Ministério da Educação. Brasília: MEC, 285336, 1998b.

[16] Tenkorang, E. Y.; Maticka- Tyndale, E. Rajulton, F. A multi-level analysis of rosk perception, poverty and sexual risk-taking among young people in Cape Town, South Africa. Health \&Place, 17 (2). 525-535, 2011.

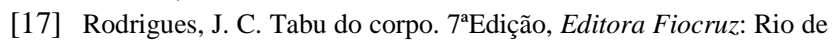
Janeiro, 2006.
[18] Mauss, M. (2003). As técnicas do corpo. In: Sociologia e antropologia. São Paulo: Cosac Naify, p. 339-422.

[19] Le Breton, D. A Sociologia do corpo. $3^{\text {a }}$ edição. Editora Vozes, Petrópolis, Rio de Janeiro, 2009.

[20] Altmann, H. Educação sexual e primeira relação sexual: entre expectativas e prescrições. Estudos Feministas, Florianópolis, 15 (2). 333-356, 2007a.

[21] Bozon, M. Sociologia da Sexualidade. Rio de Janeiro. Editora FGV, 2004.

[22] Louro, G,L. Gênero e Sexualidade: pedagogias contemporâneas. Pró-posições, 19, (2) (56), p.17-23, 2008.

[23] Carradore, V. M.; Ribeiro, P. R. M. Relações de Gênero, Sexualidade e AIDS: apontamentos para reflexão, 2004. Disponível em http://www.periodicos.udesc.br, acessado em $27 \mathrm{de}$ julho de 2011.

[24] Taquette, S. R.; Vilhena, M. M. de; Paula, M. C. de. Doenças Sexualmente Transmissíveis e gênero: um estudo transversal com adolescentes no Rio de Janeiro. Cadernos de Saúde Pública, Rio de Janeiro, 20 (1). 282-290, 2004.

[25] Scott, J. Gênero: uma categoria útil para a análise histórica. Educação e Realidade. Porto Alegre: Universidade Federal do Rio Grande do Sul; Faculdade de Educação, 20 (2). 71-99, 1995.

[26] Bozon, M.; Heilborn, M. L. Iniciação à sexualidade: modos de socialização, interações de gênero e trajetórias individuais. In: Heilborn, M. L.; Aquino, E. M. L.; Bozon, M.; Knauth, D. R. (Orgs.). O Aprendizado da Sexualidade: reprodução e trajetórias sociais de jovens brasileiros. Rio de Janeiro: Garamond e Fiocruz, p.156-205, 2006.

[27] Victora, C. G.; Knauth, D. R.; Hassen, M. N. A. A Pesquisa qualitativa em saúde: uma introdução ao tema. Porto Alegre: Tomo Editorial, Cap.1, 2000.

[28] Rodrigues, J. C. “Os corpos e a Antropologia”. In: Minayo, M. C. S.; Coimbra, Jr. C. (Orgs). Críticas e atuantes: ciências sociais e humanas em saúde na América Latina. Editora Fiocruz: Rio de Janeiro;157-182, 2005.

[29] Pimenta, D. N.; Leandro, A.; Schall, V. T. A estética do grotesco e a produção audiovisual para a educação em saúde: segregação ou empatia? O caso das leishmanioses no Brasil. Cadernos de Saúde Pública, Rio de Janeiro, 23 (5). 1161-1171, 2007.

[30] Brasil. Programa Nacional do Livro Didático para o ensino médio. PNLEM. Ministério da Educação, 2004. Disponível em www.fnde.gov.br acessado em 04 de outubro de 2009.

[31] Brasil. Parâmetros Curriculares Nacionais: apresentação dos temas transversais/ Secretaria de Educação Fundamental. Brasília: MEC/SEF, 146p, 1997.

[32] Brasil. Parâmetros Curriculares Nacionais: Temas Transversais: Orientação Sexual. Ministério da Educação. Brasília: MEC/SEF, 436p, 1998a.

[33] Brasil. Programa Nacional de DST/AIDS. Ministério da Saúde, 2010. Disponível em www.aids.gov.br acessado em 17 de maio de 2010.

[34] Andrade, C.P.; Forastiri, V.; El-Hani, C.N. Como os livros didáticos de ciências e biologia abordam a questão da orientação sexual?. Atas do III ENPEC: Encontro Nacional de Pesquisa em Educação em Ciências. Atibaia, São Paulo, 2001.

[35] Mohr, A. Análise do conteúdo de "saúde" em livros didático. Ciência e Educação, 6 (2). 89-106, 2000.

[36] Luz, Z.M.P. da; Pimenta, D.N.; Rabello, A. e Schall, V. Evaluation of informative materials on leishmaniasis distributed in Brazil: criteriaand basis for the production and improvement of health education materials. Cad. Saúde Pública, Rio de Janeiro, 19 (2): 561-569, 2003.

[37] Vasconcelos, S. D. e Souto, E. O livro didático de ciências no ensino fundamental: proposta de critérios para análise do conteúdo zoológico. Ciência e Educação, 9 (1). 93-104, 2003.

[38] Oliveira, D. C. de; Portes, A. P. M. de; Gomes, A. M. T.; Ribeiro, M. C. M. Conhecimentos e práticas de adolescentes acerca das DST/HIV/AIDS em duas escolas públicas municipais do Rio de Janeiro. Escola. Anna Nery, 13 (4). 833-841, 2009.

[39] Instituto de Saúde. Comportamento Sexual, Uso de Preservativos e Contracepção de Emergência por Adolescentes do Município de São Paulo - estudo com estudantes de escolas públicas de Ensino Médio. Figueiredo, R.; Pupo, L. R.; Alves, M. C. G. P.; Escuder, M. M. L. (Orgs.) São Paulo: Instituto de Saúde, 38p, 2008.

[40] Freire, P. Pedagogia do Oprimido, Paz e Terra, Rio de Janeiro, 2005. 
[41] Vygotsky, L. S. A formação social da mente: o desenvolvimento dos processos psicológicos superiores. Implicações Educacionais. Capítulo 6. Martins Fontes, São Paulo, 2007.

[42] Tonatto, S. E.; Sapiro, C. M. Os novos parâmetros curriculares das escolas brasileiras e educação sexual: Uma proposta de intervenção em ciências. Psicologia e Sociedade, Porto Alegre, 14 (2) . 163-175, 2002.
[43] Altmann, H. A sexualidade adolescente como foco de investimento político-educacional. Educação em Revista. Belo Horizonte, n.46; p.287-310; 2007b.

[44] Altmann, H. Orientação Sexual em uma escola: recortes de corpos e de gênero. Cadernos Pagu. v. 21; p. 281-315; 2003.

[45] Altmann, H. Sobre a Educação Sexual como um Problema Escolar. Linhas, v. 7 n. 1, 2006. Disponível em www.periodicos.udesc.br acessado em 17 de maio de 2010. 